\title{
Wyniki badań epidemiologicznych dotyczących występowania próchnicy zębów w populacji dzieci 6-letnich i 12-letnich w województwie lubuskim
}

\author{
Results of the epidemiological studies concerning dental caries \\ in 6 and 12 years old children in the Lubuskie Province \\ ${ }^{1}$ Klinika Stomatologii Dziecięcej, Katedra Stomatologii Dziecięcej, \\ Uniwersytet Medyczny im. Karola Marcinkowskiego w Poznaniu \\ 2 Zakład Stomatologii Grup Ryzyka, Katedra Stomatologii Dziecięcej, \\ Uniwersytet Medyczny im. Karola Marcinkowskiego w Poznaniu
}

DOI: http://dx.doi.org/10.20883/df.2020.4

\section{STRESZCZENIE}

Wstęp. U dzieci już od najmłodszych lat powinny zostać wdrażane programy profilaktyczne mające na celu poprawę stanu zdrowia ich uzębienia.

Cel. Celem pracy była analiza występowania próchnicy zębów u dzieci 6-letnich i 12-letnich z województwa lubuskiego w okresie objętym Ogólnopolskim Monitoringiem Stanu Zdrowia Jamy Ustnej.

Materiał i metody. Materiał badawczy uzyskany został w ramach prowadzonego na terenie województwa lubuskiego Ogólnopolskiego Monitoringu Stanu Zdrowia Jamy Ustnej oraz Projektu „Profilaktyka stomatologiczna dzieci i młodzieży z terenu miasta Gorzowa Wlkp." w latach 1999-2012. W pracy ocenie poddano frekwencję próchnicy oraz wskaźnik intensywności choroby próchnicowej dla 6-latków i 12-latków. Przedstawiono także dane dotyczące wskaźnika leczenia zębów obliczanego według wzoru W/W+P.

Wyniki. Przeprowadzona analiza wykazała, iż wartość intensywności próchnicy (PUW-z) oceniona podczas realizacji Projektu PL-0381 u dzieci 6-letnich wynosiła 0,1, podczas gdy u 12-latków miała wartość 2,69, natomiast w latach prowadzenia badań monitoringowych wartość ta kształtowała się na poziomie 2,1-4,7.

Wnioski. Stan uzębienia zarówno dzieci 6-letnich, jak i 12-letnich w województwie lubuskim jest niezadowalający. Dane wskazują na wysokie potrzeby w zakresie profilaktyki i leczenia próchnicy zębów w tym województwie.

Słowa kluczowe: intensywność próchnicy, dzieci, młodzież.

\section{ABSTRACT}

Introduction. Programs which lead to the teeth condition's improvement and to the minimization of caries intensity should focus on children since their very first years of life.

Aim. The aim of the study was to analyze the appearance of dental caries in 6 and 12 years old children from the Lubuskie Province during the National Monitoring of Oral Health program.

Material and Methods. The survey material was obtained between 1999 and 2012 in the Lubuskie Province during carrying out both the National Monitoring of Oral Health program and "The Prevention of Dental Caries in children and adolescents in Gorzow Wielkopolski" Project (PL-0381). The prevalence and intensity of dental caries was presented for the group of 6 and 12 years old children. The restorative index was also calculated according to the formula: F/F+D.

Results. The analysis showed that the value of caries intensity (DMFT) assessed during the implementation of the Project PL-0381 in children aged 6 was 0.1 whereas in 12-year-old adolescents it was 2.69, while in the years of monitoring research the values were $2.1-4.7$.

Conclusions. The dentition of both children (6-year-olds) and adolescent (12-year-olds) in the Lubuskie Province is unsatisfactory. The data indicate needs for the prevention and treatment of dental caries in this province.

Key words: intensity of caries, children, adolescents.

\section{Wstęp}

Badania stomatologiczne, prowadzone $\mathrm{w}$ ramach programu Ogólnopolskiego Monitoringu Stanu
Zdrowia Jamy Ustnej, realizowane są z inicjatywy Ministra Zdrowia i służą kontroli stanu zdrowia obywateli w różnych grupach wiekowych [1]. 
Działaniami obejmowane są dzieci oraz młodzież, osoby dorosłe, a także kobiety w ciąży [2-4]. Tym samym wszystkie uzyskane wyniki umożliwiają ocenę kliniczną stanu uzębienia zarówno populacji w okresie rozwojowym, jak i w okresie dojrzałym oraz porównanie stanu zdrowia ludności w odniesieniu do płci, wieku, miejsca zamieszkania (miasto, wieś) oraz zajmowanego obszaru kraju.

W zależności od wielkości środków przeznaczonych w danym roku, badania realizowane są w wybranych województwach i wykonywane przez lekarzy specjalistów zatrudnionych w uczelniach medycznych. Osoby biorące udział w badaniu klinicznym, w ramach przygotowania, poddane zostają kalibracji w ośrodku przewodnim (Uniwersytet Medyczny w Warszawie). Pierwszym etapem jest szkolenie teoretyczne, podczas którego przedstawione zostają kryteria oceny klinicznej, prezentowane przykładowe zmiany patologiczne, na które zwraca się uwagę w trakcie badania oraz omówiony zostaje ramowy plan postępowania. Drugi etap kalibracji stanowi badanie kliniczne, którego obiektem są pacjenci z danych grup wiekowych - adekwatnych do wybranych kryteriów monitoringu.

Przy ocenie stanu zdrowia jamy ustnej wykorzystywane są ściśle sprecyzowane kryteria opracowane przez Światową Organizację Zdrowia [5], a także kolejne ich uaktualnienia. Powyższe działania mają na celu dokonanie obiektywnej oceny zdrowia jamy ustnej wszystkich osób poddanych badaniu na terenie całego kraju.

Wyniki dotąd opublikowane, na podstawie przeprowadzonych badań epidemiologicznych, wskazują na poziom skuteczności obecnego system opieki zdrowotnej, zarówno na etapie edukacji jak i profilaktyki i leczenia [6].

\section{Cel}

Celem pracy była analiza występowania próchnicy zębów u dzieci 6-letnich i 12-letnich z województwa lubuskiego w okresie objętym Ogólnopolskim Monitoringiem Stanu Zdrowia Jamy Ustnej.

\section{Materiał i metody}

Materiał badawczy stanowiły dane z badań epidemiologicznych wykonanych w ramach Ogólnopolskiego Monitoringu Stanu Zdrowia Jamy Ustnej, prowadzonych przez Ministerstwo Zdrowia na terenie województwa lubuskiego w latach: 1999, 2000, 2001, 2005, 2008, 2010 i 2012 oraz wyniki uzyskane przy realizacji Projektu PL-0381 „Profilaktyka stomatologiczna dzieci i młodzieży z terenu miasta Gorzowa Wlkp." dofinansowanego ze środków
Mechanizmu Finansowego Europejskiego Obszaru Gospodarczego (EOG), przy wsparciu udzielonym przez Islandię, Liechtenstein i Norwegię. Informacje pozyskano z zamieszczonych na stronie Ministerstwa Zdrowia dostępnych dokumentów i analiz [7] oraz publikacji w czasopismach naukowych, a także egzemplarzy archiwalnych raportów.

Badaniem klinicznym w poszczególnych edycjach badań prowadzonych w województwie lubuskim w ramach Monitoringu Stanu Zdrowia Jamy Ustnej objęto:

> w 1999 r. - 169 dzieci 6-letnich i 208 dzieci 12-letnich,

> w 2000 r. - 134 dzieci 6-letnich i 212 dzieci 12-letnich,

> w 2001 r. - 113 dzieci 12-letnich,

> w 2008 r. - 122 dzieci 6-letnich,

> w 2010 r. - 178 dzieci 6-letnich i 180 dzieci 12-letnich,

> w 2012 r. - 226 dzieci 6-letnich i 190 dzieci 12-letnich.

Na stronach Ministerstwa Zdrowia brak było danych z badań przeprowadzonych w 2005 roku. Badania kliniczne monitoringowe zostały wykonane przez przeszkolonych stomatologów będących pracownikami Uniwersytetu Medycznego w Poznaniu (zgodnie z kryteriami WHO). Natomiast w ramach Projektu PL0381 działania przeprowadzili lekarze dentyści z 13 praktyk stomatologicznych znajdujących się na terenie Gorzowa Wielkopolskiego [8]. Badania wykonano w oświetleniu sztucznym, używając lusterka i zgłębnika.

W roku 2009 w ramach Projektu PL-0381 pt. „Profilaktyka stomatologiczna dzieci i młodzieży z terenu miasta Gorzowa Wlkp." zbadano łącznie 1001 dzieci, w tym 310 dzieci 6-letnich oraz 691 dzieci 12-letnich.

W pracy ocenie poddano wartości wskaźnika frekwencji próchnicy (dla uzębienia mieszanego dla 6-latków i zębów stałych dla 12-latków) oraz intensywności próchnicy wyrażonego średnią liczbą odpowiednio puw-Z+PUW-Z oraz PUW-Z, a także przedstawiono wskaźnik leczenia zębów obliczany według wzoru W/W+P.

\section{Wyniki}

W 1999 roku badaniem epidemiologicznym przeprowadzonym na terenie województwa lubuskiego objęto 169 dzieci 6-letnich oraz 208 osób spośród młodzieży 12-letniej [9]. W młodszej grupie frekwencja próchnicy wynosiła 84\%, natomiast w starszej 93,3\%. Intensywność próchnicy wyrażona liczbą PUW-z dzieci w wieku 12 lat miała wartość 4,7, natomiast wskaźnik leczenia 0,23. 
W roku 2000 zbadano 134 dzieci 6-letnich, u których frekwencja próchnicy wyniosła $85,1 \%$, a także 212 dzieci 12-letnich z frekwencją próchnicy równą $84,4 \%$ oraz intensywnością próchnicy (PUW-z) o wartości 3,4 i wskaźnikiem leczenia wynoszącym 0,53 [10].

W 2001 roku badaniem objęto 113 dzieci w wieku 12 lat, u których frekwencja próchnicy była równa $83,2 \%$, intensywność próchnicy (PUW-z) 3,2; a wskaźnik leczenia wyniósł 0,47 [11].

Uzyskane dane, dotyczące 2005 roku, nie uwzględniają liczby dzieci 6-letnich poddanych badaniu, natomiast podają, iż frekwencja próchnicy we wspomnianym roku wyniosła $85,6 \%$ oraz intensywność próchnicy (PUW-z) była równa 0,1 [12].

W 2008 roku u 122 badanych dzieci 6-letnich frekwencja próchnicy wynosiła $85,4 \%$, intensywność próchnicy (PUW-z) miała wartość 0,2 , natomiast wskaźnik leczenia był równy 0,04 [13].

Badania epidemiologiczne w latach 2009-2010 prowadzone były w ramach Projektu PL 0381 „Profilaktyka stomatologiczna dzieci i młodzieży z terenu miasta Gorzowa Wlkp." dofinansowanego ze środków Mechanizmu Finansowego Europejskiego Obszaru Gospodarczego (EOG), przy wsparciu udzielonym przez Islandię, Liechtenstein i Norwegię.

W roku 2009 w ramach Projektu PL 0381 pt. „Profilaktyka stomatologiczna dzieci i młodzieży z terenu miasta Gorzowa Wlkp." zbadano łącznie 1001 dzieci, w proporcji 310 dzieci 6-letnich oraz 691 dzieci 12-letnich. Podczas określania frekwencji próchnicy dzieci 6-letnich brano pod uwagę wyłącznie uzębienie stałe i otrzymano wynik $5,16 \%$. W tej grupie badanych intensywność próchnicy (PUW-z) wyniosła 0,1, a wskaźnik leczenia 0,4.Z kolei frekwencja próchnicy u dzieci 12-letnich, badanych w tym samym roku, kształtowała się na poziomie $77,7 \%$, intensywność próchnicy (PUW-z) była równa 2,69 oraz wskaźnik leczenia wyniósł 0,47.

W roku 2010 badaniem stomatologicznym we wspomnianym projekcie monitoringowym objęto 178 dzieci 6-letnich oraz 180 dzieci w wieku 12 lat [14]. W grupie młodszej frekwencja próchnicy została obliczona z wynikiem $28,6 \%$, intensywność próchnicy PUW-z wyniosła 0,08, a wskaźnik leczenia miał wartość 0,1 . W grupie starszej natomiast frekwencja próchnicy była równa $75,3 \%$, a wskaźnik leczenia 0,59.

W 2012 roku badania prowadzone w województwie lubuskim obejmowały 226 dzieci 6-letnich oraz 190 dzieci 12-letnich [15]. Frekwencja próchnicy w liczniejszej grupie wyniosła $88,1 \%$, natomiast w mniej licznej $68,4 \%$. Z kolei intensywność próch- nicy (PUW-z) w obu badanych grupach była równa odpowiednio 0,04 oraz 2,1, a wskaźnik leczenia wyniósł odpowiednio 0,25 oraz 0,4 .

\section{Dyskusja}

Stan uzębienia zarówno dzieci 6-letnich, jak i młodzieży w wieku 12 lat w województwie lubuskim jest niezadowalający. Mimo że porównywane rezultaty były uzyskane w odniesieniu do różniących się liczebnością grup badanych, a badania zostały wykonane odpowiednio przez epidemiologów i lekarzy praktyków (być może nie zawsze stosujących wytyczne WHO), dane wskazują na wysokie potrzeby w zakresie profilaktyki i leczenia próchnicy zębów w tym województwie. Pomimo podnoszenia poziomu świadczeń zdrowotnych w sektorze opieki stomatologicznej, zwiększającej się liczby gabinetów oraz edukacji zdrowotnej społeczeństwa, Polacy w badaniach epidemiologicznych dotyczących zdrowia jamy ustnej nadal wypadają niekorzystnie na tle mieszkańców innych krajów Europy [16]. Wydaje się, że wynika to przede wszystkim z niewiedzy oraz zaniedbań rodziców często bagatelizujących znaczenie profilaktyki choroby próchnicowej zębów, którzy nie dostrzegają potrzeby leczenia zębów mlecznych [17].

Należy zaznaczyć szczególną rolę szkoły, która jako placówka nauczania i wychowania posiada kluczowe znaczenie zarówno dla zdrowia dzieci, ale także ich rodziców oraz nauczycieli [18]. Podejmowane $w$ tym środowisku różnego rodzaju inicjatywy, mające na celu edukację prozdrowotną, zwiększają możliwość uzyskania dobrych rezultatów [19].

Dlatego też organizacje zajmujące się zdrowiem jamy ustnej, na czele ze Światową Organizacją Zdrowia, wskazują, że efektywne przeciwdziałanie próchnicy powinno być osiągane dzięki edukacji w środowisku domowym połączonej ze zdobywaniem wiedzy na ten temat w przedszkolu i szkole oraz uczestnictwem w stomatologicznych programach zdrowotnych [20]. Przykładem może być program stomatologicznej edukacji prozdrowotnej w ramach projektu "Edukacja, promocja i profilaktyka w kierunku zdrowia jamy ustnej skierowana do małych dzieci, ich rodziców, opiekunów i wychowawców", który był adresowany do dzieci w wieku 0-5 lat, ich rodziców, opiekunów, nauczycieli przedszkolnych, pielęgniarek i położnych oraz lekarzy. Edukacja w ramach Projektu odbywała się na drodze bezpośredniej oraz pośredniej, z wykorzystaniem materiałów edukacyjnych, takich jak: broszury, ulotki, plakaty, filmy i lekcje dla dzieci w wieku przedszkolnym [21, 22]. W celu sze- 
rzenia świadomości przeciwpróchnicowej wśród przyszłych rodziców w szkołach rodzenia, w latach ubiegłych, PTS zrealizował "Program stomatologicznej edukacji prozdrowotnej dla przyszłych rodziców" w ramach międzynarodowej inicjatywny [23]. Działania takie wydają się niezwykle istotne, gdyż zezwalają na poprawę stanu zdrowia jamy ustnej zarówno matek, ale także ich dzieci. Natomiast miejscem prowadzenia przedsięwzięć edukacynych, z zakresu zdrowia jamy ustnej, dla przyszłych rodziców oraz tych opiekujących się małymi dziećmi mogą być między innymi szkoły rodzenia czy poradnie laktacyjne [24].

Ponadto konieczne jest zwiększenie dostępności specjalistów z dziedziny stomatologii dziecięcej oraz gabinetów specjalnie przygotowanych do pracy z pacjentem pediatrycznym [25]. Należy podkreślić, iż wizyty u lekarza stomatologa powinny się odbywać systematycznie, celu podjęcia działań profilaktycznych i aby uniknąć sytuacji, w których dziecko trafia do gabinetu dentystycznego na pierwszą wizytę, jako interwencyjną, dopiero w momencie wystąpienia dolegliwości bólowych zębów. Sporadyczne wizyty u lekarza stomatologa uniemożliwiają nawiązanie pozytywnego kontaktu z dzieckiem oraz zachęcenie do przeprowadzania procedur profilaktycznych i leczniczych. Ponadto brak współpracy i czynnego zaangażowania ze strony rodziców/ pełnoprawnych opiekunów w kształtowanie właściwych nawyków higienicznych oraz dietetycznych nie sprzyja zdrowiu jamy ustnej [25].

W podsumowaniu należy podkreślić, iż rezultaty uzyskane $w$ badaniach epidemiologicznych wskazują na potrzebę zintensyfikowania zachowań prozdrowotnych wśród dzieci i młodzieży populacji polskiej, zwłaszcza w środowiskach skupiających osoby najmłodsze, a także rozpowszechnienia profilaktyki oraz zwiększenia świadomości na temat chorób jamy ustnej oraz sposobu ich rozwoju. Nacisk, jaki kładzie się na element sektora edukacji związany z działaniem przeciwpróchnicowym, ma na celu zminimalizowanie choroby próchnicowej oraz ryzyka jej rozwoju we wspomnianych grupach wiekowych.

\section{Wnioski}

Stan uzębienia zarówno dzieci 6-letnich jak i 12letnich w województwie lubuskim jest niezadowalający, choć na przestrzeni obserwowanego okresu ulega pewnej poprawie.

Mimo że porównywane dane uzyskane były w odniesieniu do różniących się liczebnością grup badanych (w monitoringu i projekcie), a także badania zostały wykonane odpowiednio przez epide- miologów i lekarzy praktyków (nie zawsze stosujących wytyczne WHO), dane wskazują na wysokie potrzeby w zakresie profilaktyki i leczenia próchnicy zębów w tym województwie.

\section{Oświadczenia}

Oświadczenie dotyczące konfliktu interesów Autorzy deklarują brak konfliktu interesów w autorstwie oraz publikacji pracy.

\section{Źródła finansowania}

Autorzy deklarują brak źródeł finansowania.

\section{Piśmiennictwo}

[1] Strużycka I, Wierzbicka M, Jodkowska E, Rusyan E, Ganowicz M, Ziemiecka K. Wyniki Monitoringu Stanu Zdrowia Jamy Ustnej populacji młodych dorosłych w Polsce w 2012 roku. Nowa Stomatol. 2013;18,4:195-199.

[2] Gaszyńska E, Klepacz-Szewczyk J, Trafalska E, Garus-Pakowska A, Szatko F. Dental awareness and oral health of pregnant women in Poland. Int J Occup Med Environ Health. 2015;28,3:603-611.

[3] Strużycka I, Wierzbicka M, Jodkowska E, Rusyan E, Ganowicz E, Fidecki M. Oral health and prophylactic needs of children aged 6 years in Poland in 2012. Przegl Epidemiol. 2014;68:53-57.

[4] Gerreth K, Wróblewska S, Gerreth P, Borysewicz-Lewicka M. Choroba próchnicowa zębów u dzieci i młodzieży w województwie lubuskim na podstawie badań prowadzonych w ramach „Ogólnopolskiego Monitoringu Stanu Zdrowia Jamy Ustnej". Stomatol Współcz. 2019;26,1:71-74.

[5] WHO: Oral Health Surveys. Basic methods 1997. 4th ed. WHO, Geneva 1997.

[6] Staszczyk M, Kępisty M, Kołodziej I, Kościelniak D, Gregorczyk-Maga I, Ciepły J, Jurczak A. Ocena stanu i trend próchnicy u dzieci 5-, 7- i 12-letnich z województwa małopolskiego w porównaniu do populacji polskiej. Nowa Stomatol. 2018;23,2:55-65. https:// doi.org/10.25121/NS.2018.23.2.55.

[7] https://www.gov.pl/web/zdrowie/monitorowanie-stanu-zdrowia-jamy-ustnej-populacji-polskiej-w-latach-2016-2020

[8] Chłapowska J. Gorzowskie dzieci bez ubytków. Fakty UMP 2010;11,4:6-7.

[9] Wierzbicka M, Szatko F, Radziejewska M, Rucińska K, Zawadziński M. Ogólnokrajowy Monitoring Zdrowia Jamy Ustnej i Jego Uwarunkowań (drugi etap 1999 rok). Dzieci w wieku 6 i 12 lat. Warszawa 1999.

[10] Wierzbicka M, Szatko F, Rucińska K, Zawadziński M. Ogólnokrajowy Monitoring Zdrowia Jamy Ustnej i Jego Uwarunkowań. Dzieci w wieku 6, 11 i 12 lat. Polska 2000.

[11] Wierzbicka M, Szatko F, Rucińska-Szysz K, Zawadziński M. Ogólnokrajowy Monitoring Zdrowia Jamy Ustnej i Jego Uwarunkowań. Polska 2001.

[12] Ganowicz M, Wierzbicka M, Pierzynowska E, Zawadziński M, Jodkowska E. Występowanie próchnicy u dzieci w wieku 6 lat w Polsce w 2005 roku. Nowa Stomatol. 2007;1:3-7. 
[13] Wyniki badań epidemiologicznych prowadzonych w ramach programu "Monitoring Zdrowia Jamy Ustnej" w 2008 i 2009 roku. https://www.gov.pl/ web/zdrowie/monitorowanie-stanu-zdrowia-jamy-ustnej-populacji-polskiej-w-latach-2016-2020 [dostęp z dnia 25.04.2020]

[14] Wyniki badań epidemiologicznych prowadzonych w ramach programu „Monitoring Zdrowia Jamy Ustnej" w 2010 roku. https://www.gov.pl/ web/zdrowie/monitorowanie-stanu-zdrowia-jamy-ustnej-populacji-polskiej-w-latach-2016-2020 [dostęp z dnia 25.04.2020]

[15] Wyniki badań epidemiologicznych prowadzonych w ramach programu "Monitoring Zdrowia Jamy Ustnej" w 2012 roku. https://www.gov.pl/ web/zdrowie/monitorowanie-stanu-zdrowia-jamy-ustnej-populacji-polskiej-w-latach-2016-2020 [dostęp z dnia 25.04.2020]

[16] Da Silveira Moreira R. Epidemiology of Dental Caries in the World. W: Oral Health Care - Pediatric, Research, Epidemiology and Clinical Practices, str. 149168. DOI: 10.5772/31951. http://cdn.intechopen. com/pdfs-wm/29340.pdf [dostęp z dnia 7.05.2020].

[17] Chłapowska J. Stan zdrowia jamy ustnej małych dzieci w Polsce. W: Zdrowie jamy ustnej małego dziecka. Poradnik dobrych praktyk w kształtowaniu zachowań prozdrowotnych w placówkach nauczania i wychowania, organach samorządowych i organizacjach pozarządowych w Polsce. Poznań: Uniw. Med. im. Karola Marcinkowskiego w Poznaniu; Wydaw. Med Tour Press Int., 2016:16-20.

[18] Petersen P.E. Improvement of global oral health the leadership role of WHO. Community Dent Health. 2010;27:194-199.

[19] Wierzbicka N, Kaczmarek U. Trend choroby próchnicowej u 12-letnich dzieci na podstawie badań monitoringowych stanu zdrowia jamy ustnej. Czy polskie dzieci mają szanse na osiągnięcie narodowego i europejskiego celu zdrowia jamy ustnej? Dent Med Probl. 2009;46,2:149-156.
[20] Borysewicz-Lewicka M, Gerreth K. Działania populacyjne w zapobieganiu chorobie próchnicowej zębów. Stom. Współcz. 2016;23,3:36-39.

[21] Borysewicz-Lewicka M, Gerreth K, Gmerek P. Program stomatologicznej edukacji prozdrowotnej w ramach projektu "Edukacja, promocja i profilaktyka w kierunku zdrowia jamy ustnej skierowana do małych dzieci, ich rodziców, opiekunów i wychowawców". Stom Współcz. 2015;22,4:26-29.

[22] Borysewicz-Lewicka M, Gerreth K, Gmerek P. Promowanie zdrowia jamy ustnej dzieci przedszkolnych materiały edukacyjne. Dent Forum. 2015;43,2:99102.

[23] Borysewicz-Lewicka M, Opydo-Szymaczek J, Lewicka-Rabska A, Miądowicz-Owczarzak K, Gerreth K. Edukacja stomatologiczna w szkołach rodzenia w ramach ogólnopolskich projektów zdrowotnych. Stom Wspolcz. 2015;22,6:8-12.

[24] Kuśmierz K, Węgrzyniak M, Pawłowska A, Czerwonka K, Małkiewicz K. Występowanie próchnicy zębów u dzieci w wieku 3, 6 I 12 lat. Med Og Nauk Zdr. 2016;22,3:190-193.

[25] Chłapowska J, Gerreth K, Pilipczuk-Paluch K, Borysewicz-Lewicka $M$. Ocena dynamiki próchnicy u 6-letnich dzieci z województwa lubuskiego. Dent Med Probl. 2012;49,2:166-172.

Zaakceptowano do edycji: 2020-06-01 Zaakceptowano do publikacji: 2020-06-15

Adres do korespondencji: Katedra Stomatologii Dziecięcej Uniwersytet Medyczny im. Karola Marcinkowskiego w Poznaniu ul. Bukowska 70, 60-812 Poznań tel.: 618547053, fax.: 618547059 e-mail: klstomdz@ump.edu.pl 